\title{
The changing symbolic meaning of the extinct great auk and its afterlife as a museum object at the Natural History Museum of Denmark
}

\section{KATLA KJARTANSDóttir}

\begin{abstract}
This article examines the historical context and afterlife of the great auk as a museum object. The focus is on the changing meaning of the bird as it travels across cultural boundaries, material forms and historical periods. It starts by focusing on how the bird was contextualized within Ole Worm's cabinet in the 17th century and then moves on to more recent museum representations. By conducting interviews with museum staff and professionals and analysis of items stored and/or exhibited at the museum, the symbolic meanings and representative functions of the great auk are brought into light. As proposed in this paper, certain characteristics, values and meanings stem from the materiality of the objects but also from their travels and re-locations. The investigation reveals how the role of the great auk in relation to collective museum (and human) challenges such as emerging ecological limits and biodiversity loss has been developing.
\end{abstract}

Keywords: Taxidermy, objects, colonialism, cabinets of curiosity, thing power, great auk.

The main research question of this article is how the symbolic meaning of the great auk, as a museum object, has developed as it moves across cultural boundaries, museum narratives and historical periods. ${ }^{1}$ Interrelated questions will also be examined regarding colonial encounters and how the great auk has functioned as a cultural agent, conveyance and exotic commodity. I investigate these questions, through critical analysis of diverse great auk museum items exhibited and/or stored at the
Natural History Museum of Denmark because the museum played a fundamental role in preserving valuable biological information and the very rare physical remains of the bird. I propose that the great auk as a museum object in diverse forms is "a slow event" (KirshenblattGimblett 2004:59) and reveal how the values, meanings and significances of several great auk museum items are created through narrations, contextualizations and re-locations.

The flightless bird known as the great auk 
has been extinct since the 19th century, but there are around 80 taxidermied specimens held in museums worldwide, most of which came from Iceland. The great auk, Pinguinus impennis, was found in huge numbers across the North Atlantic. Its closest living relative is the razorbill, and it is related to puffins, guillemots and murres (Fuller 1999). The examples mentioned in the article demonstrate the ways in which the great auk has been contextualized as a museum object at the Natural History Museum of Denmark and how its symbolic meaning has developed over time.

The research material was gathered using a combination of semi-structured interviews with museum staff and professionals at the Natural History Museum of Denmark and an analysis of museum collections, museum archival material, photographs and great auk museum objects. The great auk has, throughout history, played several roles within the Natural History Museum of Denmark since it first appeared as a living animal within Ole Worm's cabinet of curiosity in the 17th century. I suggest that, within his cabinet, the bird as a museum object took part in circulating ideas about the distant and exotic North (the peripheries of the Danish empire) while creating valuable knowledge about the nature of the area along with other items collected and displayed in the cabinet. ${ }^{2}$ Soon after its extinction in the mid 19th century, the great auk was turned into an iconic symbol of extinction and has frequently been generated as such in order to evoke ecological awareness and concern in relation to biodiversity (See Lorimer 2014 and Gremaud 2014 as examples of how the great auk has been displayed in British and Icelandic contexts).

Post-human scholars, within diverse fields (e.g. Haraway 1985, Latour 1987, Bennett 2004, 2010, Snæbjörnsdóttir \& Wilson 2006,
Braidotti 2013, Olsen and Pétursdóttir 2014, Ferrando 2016) have stressed the importance of materiality and non-human actants as coproducers and important compatriots of our world. According to Jane Bennett (2004), an actant is either human or non-human, or simply that which "does something, has sufficient coherence to perform actions, produce effects, and alter situations" (355). For Bennett (2004), this attentiveness to (nonhuman) things and their powers is interlinked with a concern for ecological matters. She speculated whether sensitivity to things and non-humans might induce a stronger ecological sense and foster a greater ethical appreciation of the force of things. In line with these theoretical developments, I approach the great auk as an important compatriot and nonhuman actant in my investigation.

I suggest that the bird, as a living animal and later a museum object, has served as such a non-human actant by revealing how it has influenced complex social, economic and cultural entanglements and power relations across national borders and throughout historical periods. In order to support this argument, the article gives examples of how the bird, as a museum object in diverse forms, has shaped cross-cultural entanglements while travelling between indigenous hunters in the North Atlantic, Danish merchants, private collectors and museums and how it ended up as a dark reminder of the overexploitation of natural resources and complete extinction of species.

\section{THE GREAT AUK AND OTHER EXOTIC ITEMS FROM THE NORTH IN OLE WORM'S CABINET}

In the seventeenth century, Danish antiquarian Ole Worm (1588-1654) had a living great auk 
from the Faroe Islands as a pet in his cabinet of curiosities (Wormianum 1655, Steenstrup 1857 Grieve 1885). In his cabinet, a taxidermy of this peculiar pet was later exhibited with other so-called rare and exotic items that, at the time, were used to create knowledge about distant places such as the North and to evoke curiosity and wonder among visitors (Mordhorst 2003; Hafstein 2003; 2010). In contemporary times, visitors can also be filled with wonder and awe when entering Rosamund Wolff Purcell's remarkable installation All Things Strange and Beautiful. The exhibit re-creates Worm's cabinet in a very precise way and is currently exhibited at the Natural History Museum of Denmark. As indicated on a text panel, natural wonders and peculiarities are certain key elements that Worm was concerned with, but it is also evident that his interest and focus was very much directed towards areas of the North Atlantic: Iceland, Greenland and the Faroe Islands (see also Mordhorst 2003, Hafstein 2003). ${ }^{3}$

As can be seen when examining Purcell's recreation of Worm's cabinet at the Natural History Museum of Denmark, a number of exotic items from the North-Atlantic area were carefully and systematically placed within the cabinet, such as a stuffed great auk specimen from the Faroe Islands, a stuffed Atlantic puffin hanging from the ceiling, a taxidermy of a small polar bear and a stuffed polar bear head, a kayak, a narwhal skull from Iceland, a whalebone, and Greenlandic animal skin clothing (The Natural History Museum of Denmark, September 2018). These items, and information about them gathered through correspondence with local informants, played a fundamental role in creating an extensive system of material knowledge regarding both the nature and culture of the area. Through emphasising wild, exotic and strange animals such as the great auk, whales and polar bears, along with the traditional hunting cultures of the area, Worm's grand collection of material also produced and circulated a particular visual narration of the area.

By collecting objects from the North and then ordering them within his own system, Worm did not merely create some kind of illusive image of the area. Through his collecting approach and his emphasis on displaying tangible objects, a concrete and hands-on knowledge was also created. Worm wanted visitors to touch the objects in order to acquire, what Worm himself called, "intimate knowledge" (Schepelern 1965-1968, II:132 in Hafstein 2003:9). Worm's interest and focus towards the Arctic has been highlighted (e.g. Hafstein 2003, Mordhorst 2003). A text panel at the Natural History Museum of Denmark states that "Worm was hardly interested in the native Danish fauna, when it was a question of genetic abnormalities or other freakish phenomena. The Arctic fauna was more intriguing to him" (Natural History Museum of Denmark, September 2018). ${ }^{4}$ In Worm's cabinet, there were also several other objects from Iceland, such as pairs of woollen stockings, carved chess men, a barrel of mutton and peculiar stones (Worm and Benediktsson 1948:XXXII). In addition to these items, one could also see Icelandic flutes and a reindeer sleigh from the Sami of northern Scandinavia (Hafstein 2003). This collection of diverse material bears witness to his interest and focus towards the North-Atlantic as a region of wonder and difference.

In 1605, Worm went on a grand tour and visited major European cities such as London, Paris and Amsterdam (Hafstein 2003), but despite his interest in the North, he never travelled to Iceland, the Faroe Islands or Greenland. For several years, however, Worm 


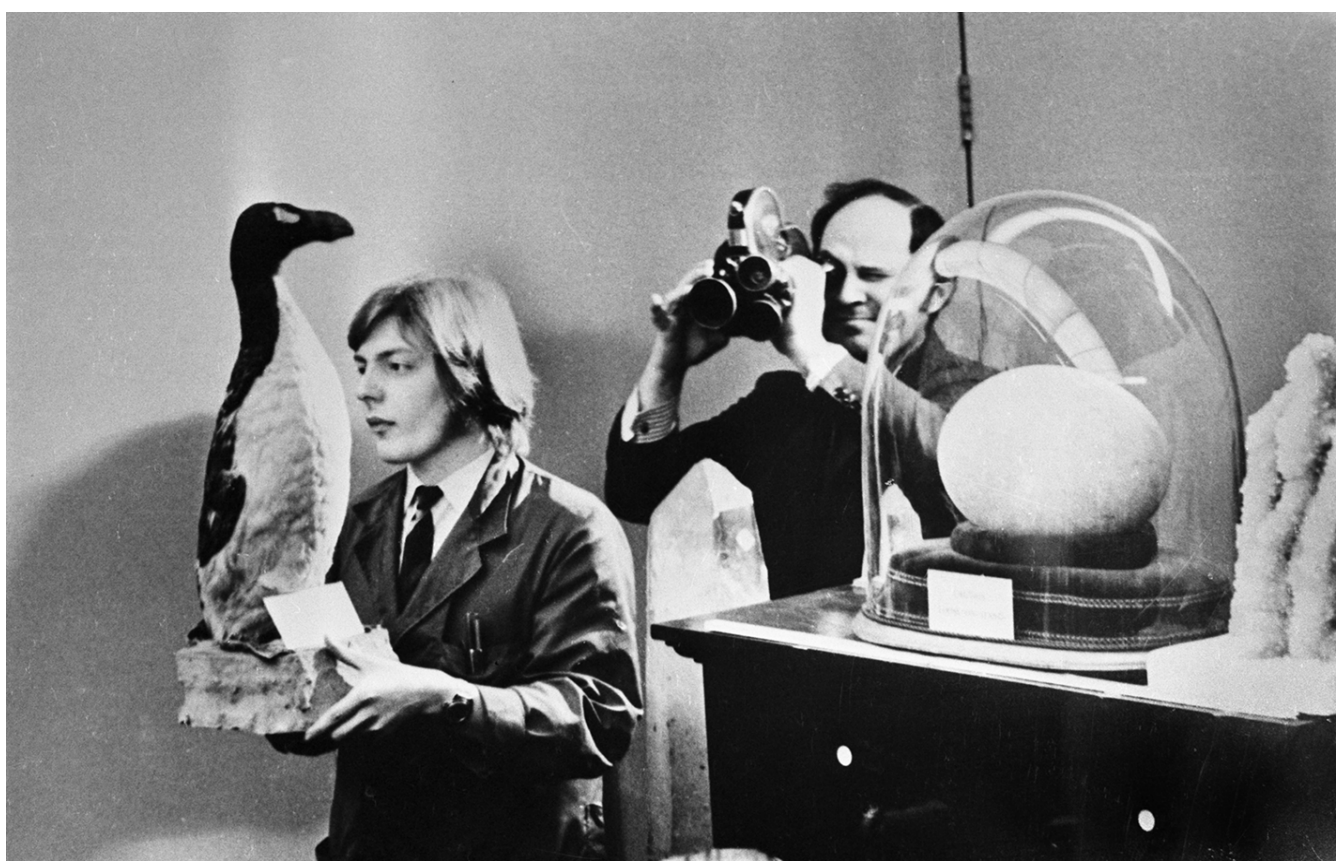

Fig. 1. Image from the Sotheby's auction in 1971. Photo: Reykjavik Museum of Photography.

exchanged letters with a number of Icelanders, such as Arngrímur Jónsson (1568-1648), known as the learned. Through these letters, he attained valuable knowledge in relation to the nature of the area and information about old Nordic runes, animal biology and literary texts (Worm \& Benediktsson 1948, Worm 1965, Shackelford, 1999, Hafstein 2003). This highlights the role of his collection in moulding ideas about the area and how the great auk became part of a knowledge system and visual narrative about the wild and exotic North.

When placed within Ole Worm's cabinet, any object instantly became part of a certain classification system, museum narrative and world view produced by Worm. Within this context, one can imagine that the object played a significant role in the exotification or othering of the North. At the time, the image of the North was rather dreamlike, as if it were a very distant and far-away place where, according to the images, primitive people or noble savages lived in close connection with nature (e.g. Davidson 2005, Kjartansdóttir 2009, Ísleifsson 2011, Schram 2011, Byrne 2013, Loftsdóttir 2015). Along with other rare items attained from the area, the great auk became a signifier of colonial governance, territorial claiming - and the exotic North. Material collections such as these were strongly interlinked with exploitation of natural resources and distribution of exotic commodities from the North-Atlantic area (Davidson 2005). The collecting and displaying of material things, such as the great auk, was an essential part of 
the early-modern European world order and a mind-set, which simultaneously strengthened the position of colonial powers and validated the idea of human supremacy over nature. These ideas underpinned the manipulation and tractability of nature and encouraged centre/periphery power relations.

\section{GreAT AUK ITEMS COLLECTED IN THE 19TH CENTURY}

Similarly, material culture and the circulation of diverse objects also played significant parts in the image making of the North during the 18th and 19th century (Byrne 2013). Artefacts collected by northern travellers were both souvenirs of their travels and evidence of their experiences. They were representations of the new information awaiting collection and analysis, curios and material expressions of the gentlemanly curiosity that inspired travel and scholarly enquiry, and material expressions of metropolitan perceptions of northern cultures. These objects acted as both curious novelties and as sources of information (Byrne 2013). A variety of this kind of souvenir collections were later put on display to present the far North in ethnographic museums of the British and the Danish empires (Byrne 2013). It is through such objects, texts and images that an exotic, or even fantastical, image of the North has continually been negotiated, narrated and displayed. Wild, exotic, and sometimes stuffed, animals, such as great auks, penguins, puffins and polar bears, have also played significant parts in creating and sustaining this image through the ages (e.g. Davidson 2005, Snæbjörnsdóttir \& Wilson 2006). As discussed above, this image of the North was moulded by well-educated and traveling men, such as Ole Worm, and their way of ordering the world (Foucault 1970) through their personal views, narrations, texts, drawings, photographs, object collections and representations of people, places and things.

The 19th century was before the advent of animal documentaries and colour photography. Thus, museums were crucial venues for the general public to learn about nature, and taxidermy was the primary technology for making creaturely life visible (Poliquin 2012). In the mid 19th century, Iceland was still a part of the Danish kingdom, and according to Newton (1861), Danish merchants and collectors were in the forefront of collecting the last living great auks in Iceland in 1821 and 1844. A taxidermy of the bird, which was killed in Iceland in 1821, was owned by count Fredrik Christian Raben, a Danish collector, traveller and amateur botanist, and remained in his family until it was sold at a Sotheby's auction (Fig. 1) and bought for nine thousand and three hundred pounds by the Icelandic state in 1971 (Petersen 1995). ${ }^{6}$

In the 19th century, other natural scientists such as Alfred Newton and his comrade John Wolley (1823-1859) also became interested in the great auk and made trips to Iceland to collect great auk eggs (Newton 1861). When Newton and Wolley visited Iceland, they were too late, as the bird was already extinct by then. The duo did, however, manage to interview some of the Icelandic men who took part in killing the last two birds (Newton 1861). According to Newton's notes, a hunting trip was made to the island of Eldey on the third of June 1844 in "Satan's weather" (Newton 1861:19) to capture the birds for the Danish collector and merchant Carl Franz Siemsen (1829-1907). These two birds, a male and a female, were the two last living specimens of the great auk. They were sold to another Danish merchant in Reykjavík, Christian Hansen, who sold them to Möller, a Danish apothecary in Reykjavík, with their 
bodies and organs (including eyes, stomach, liver and hearts) ending up in the collection of the Museum of Zoology at the University of Copenhagen.

The internal organs, including the eyes, stomach, liver and the hearts (Fig. 2), of the last two birds are still used for contemporary research and knowledge production. Valuable biological and genetic information about the bird can be gathered from these samples, for instance regarding their internal bacterial flora, digestive system and how deep they could dive (Interviews with museum staff and professionals at the Danish Natural History Museum, September-October 2018). There are also currently an egg, skulls and diverse great auk bones from Iceland, Greenland, Denmark and Newfoundland (Canada) along with two mounted great auks, one from Greenland and one from Iceland, as part of the museum collections.

\section{OBJECTS ON THE MOVE}

As can be seen from the diverse examples discussed throughout the article, the great auk has been quite mobile, and on its travels as a museum object, it has experienced a wide range of sensations and relations. The travels, effected, narratives and traces of diverse crosscultural relations add, in my view, extensively to the value, power and symbolic meaning of the great auk as a museum object. Without the layers and threads gained on its journeys, the object would not have the same rich and multilayered meaning or symbolic value attached. It would, in other words, not have the same thing power (Bennett 2004) or effect on the visitor.

These, and other examples discussed in the article, also reveal how interlinked the great auk is with the history and development of the Natural History Museum of Denmark (see

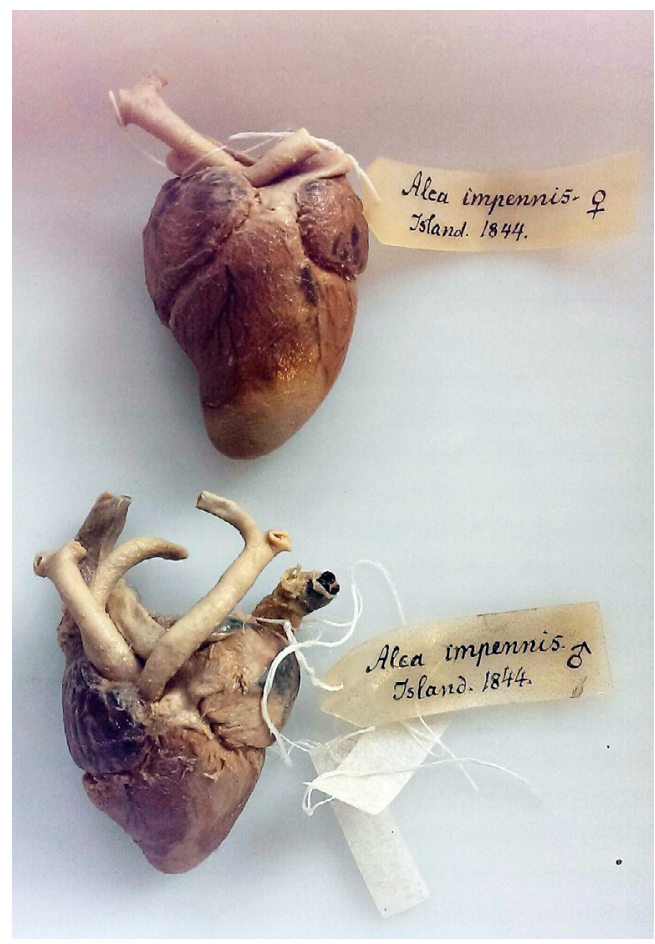

Fig. 2. The two hearts from the last great auks hunted in Eldey, Iceland in 1844. Photo: Jessica Thomas, 2015.

also Fjeldså \& Hatting 1985, Lyngs 1994). As mentioned by one of my informants, and will be discussed below, the museum was once known as the museum that could provide other museums with great auk specimens. As pointed out by Grieve (1885), the museum in Denmark provided great auk skins for museums in Austria, Germany, England and Switzerland. Great auk skins were also exchanged for other rare and valuable objects such as an Indian tapir that was traded with the Museum of Mainz in 1860 (Grieve 1885).

Another example is the fact that on the museum's birthday, November 2, the mounted great auk specimen from Iceland has been 
taken out from the exhibition halls and placed at the entrance of the museum for visitors to marvel at up close. These examples indicate how treasured the great auk is at the museum and as one of my informants said: "the great auk is very much at the heart of the museum and the collections" (Interviews with museum staff and professionals, September-October, 2018). My informant's phrasing also highlights the fact that the Natural History Museum of Denmark currently preserves the two hearts (Fig. 2) of the last great auk specimens hunted in Iceland in 1844.

\section{TWO MOUNTED SPECIMENS FROM ICELAND AND GREENLAND - AND ONE PLASTIC REPLICA}

The Greenlandic specimen (Fig. 3) was hunted and killed in Greenland in 1815 by a Greenlandic hunter in Fiskenæsset (Qeqertarsuatsiaat) and delivered to Mr. Heilmann, the director of the Royal Greenlandic Trading Company in Qeqertarsuatsiaat. In 1842, it was sold to the director of the Zoological Museum in Copenhagen, J. Reinhardtsen (Meldgaard 1988). This provenance is a very clear example of how the bird was, at this point in time, turned into a very valuable commodity, cultural product and a rare museum object. It can also be seen as a relic of complex colonial relations and 19th century ideologies regarding human/ animal relations.

This highly valuable museum object is mainly kept in the storage room in order to keep it from sunlight and deterioration. It certainly appears to be quite fragile and delicate, but when discussing the item with the museum staff and professionals, they described it as very effective. When students come to visit the museum, they are sometimes allowed to see this item after they have

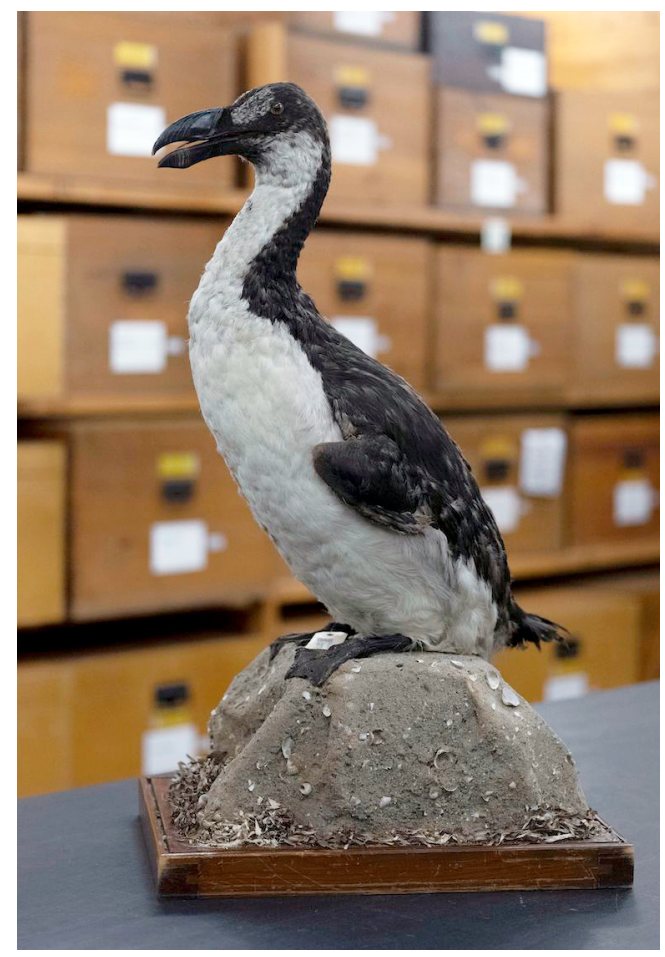

Fig 3. The Great Auk Specimen, hunted in Greenland in 1815. Photo: Brian Berg, 2019.

strolled around the exhibition halls. Then, as described by one member of staff, "they finally say wow" (Interviews with museum staff and professionals at the Natural History Museum of Denmark, September-October 2018). These visitor responses clearly show the vitality or thing power (Bennett 2004) of this item and how capable it is of stirring up emotions. The fact that it is only displayed on special occasions also adds to the dramatic effect of the object, as mentioned by my informants. These examples show how the bird as a museum object in diverse forms has been used, sometimes as a surprise element, to affect museum visitors and to evoke and circulate 
joyful emotions among the museum staff. For the museum staff and professionals, it has also been used to remind them of their main role of producing knowledge and creating awareness about nature (Interviews with museum staff and professionals at the Natural History Museum of Denmark, September-October, 2018 and January-August, 2019).

According to my informants, this valuable artefact is never presented in the exhibition halls. In its place is a plastic replica (Fig. 6) made by Ole Post, a former conservator at the Natural History Museum of Denmark (Interviews with museum staff and professionals at the Natural History Museum of Denmark, SeptemberOctober, 2018 and January-August, 2019). The replica is displayed as part of an exhibition called From the North Pole to the South Pole, which partly emphasises Arctic animals, climate and nature. The manufactured character of this item is quite striking, and somehow, it reminded me of a rubber duck. In comparison with the thing power (Bennett 2004) of the real thing (Fig. 3), which is one of two specimens in winter plumage that exist in the world and the only great auk from Greenland (Meldgaard 1988), the plastic one undeniably became a bit inane (Natural History Museum of Denmark, September 2018).

I will return to this interesting object, but now I will focus on the other very rare mounted great auk specimen currently preserved at the museum and the internal organs from the two last birds, hunted in Iceland in 1844. The organs are neatly organized in four glass jars and exhibited above the head of the Icelandic specimen in a small and rather dimly lit part of the exhibition space. These items are contextualized within the exhibition Precious Things that was launched in 2015, and also includes Misty the dinosaur (a diplodocus fossil), a dodo skull and the heart of the Greenland whale. As can be seen in the photograph by Maja Theodoraki (Fig. 4) and published in the exhibition catalogue Precious Things. The Greatest Treasures of the Museum (2015), the object is staged quite dramatically for the photoshoot. The small plate under its feet, the black velvet surroundings and the stark spotlight give the object exalted attention and the impression of being a celebrity or even a rock star. Dark walls and dim lights in the exhibition area, however, hint at the dark and dramatic undertones of these valuable museum objects, the mounted bird hunted in Iceland in 1823 and the internal organs of the two last birds, hunted in Iceland in early June 1844.

On a large panel that is also part of the Precious Things exhibition but located a bit strangely in the staircase at the museum, the killing of the last great auk pair is remembered with the following, rather dark and disturbing, quote: "As I held its neck, its wings stuck out a bit. I grabbed it around the neck, and it flapped its wings. It made no sound. I wrung its neck. Sigurdur Isleifsson about his meeting with the last great auk, 1844." The odd placement of this text panel in a somewhat liminal space, a white and greyish staircase, adds a chilling layer to this rather morbid narrative. This quote, chosen by the curators of the Precious Things exhibition, places the object within the rather stereotypical narrative and image making of the North as a primitive or exotic space where savages seem to be roaming around killing wild animals with their bare hands. ${ }^{6}$ The description was originally published in Newton's (1861) book and is a very clear example of how certain narratives have been attached to the object to travel with it across historical periods and diverse cultural contexts. The dimly lit exhibition space and dramatic staging of the mounted bird, accompanied by the panel text 
The CHANgING SYMBOLIC MEANING OF THE EXTINCT GREAT AUK AND ITS AFTERLIFE as a museum object at the Natural History Museum of Denmark

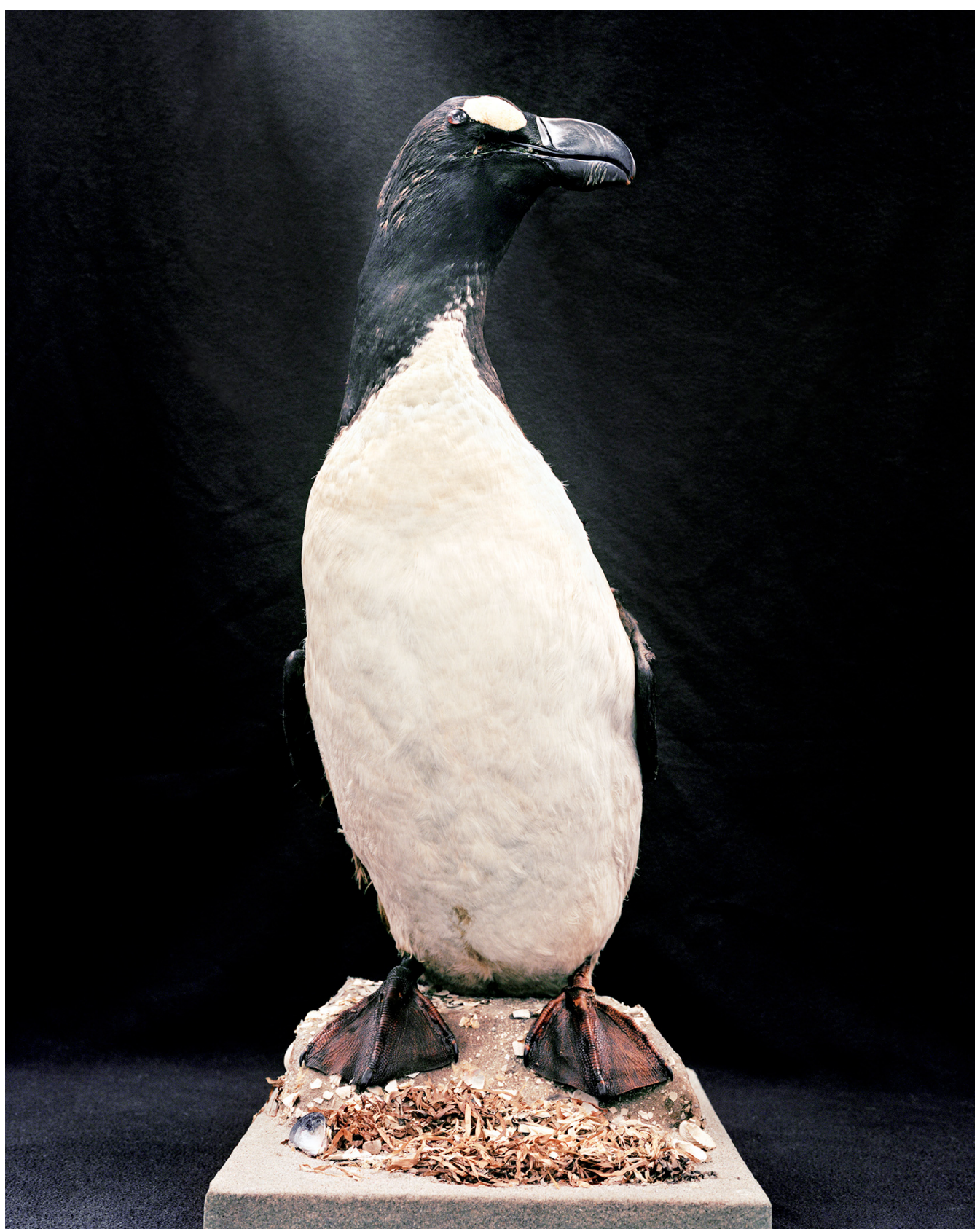

Fig. 4. Icelandic specimen hunted in Eyrabakki in 1823. Photo: Maja Theodoraki, 2015. 
with its emphasis on the unpleasant details of the killing of the last birds, also highlights the symbolic meaning of the great auk as a dark reminder of dark ecological matters (Morton $2007 ; 2010 ; 2013)$ such as the overexploitation of natural resources and the complete extinction of a species.

When I asked one of my informants at the Natural History Museum of Denmark about the main role and symbolic meaning of the great auk, he described it as a very valuable, rare and iconic object that can serve as a reminder of the damage humans can cause nature in relation to overexploitation. Further, he described it as "an example of a vulnerable species that was hunted to extinction by humans" and an "iconic example of what can happen to nature if humans overexploit it" (Interviews with museum staff and professionals, SeptemberOctober 2018). Another informant answered my question through e-mail and said:

The Zool.Museum in Copenhagen (an independent institution unit the formation of the unified Natural History Museum few years ago) was once widely known as the institution that could provide great auk specimens, at a time when there was no awareness about extinction risks. In the early 1800 s it was simply not believed that species could go extinct, as this was contrary to the concepts about 'Gods creation'. So it was an important lesson, which was symbolized by the use of the Great Auk as a logo for the museum (a logo that we are no longer allowed to use, because of decision by the university leadership to use a common 'corporate image' for all units within the university).

Another staff member responded, also through e-mail, and stated that:

Overall, the great auk specimens are a symbol of extinction. They are a physical reminder of the consequences of short-term thinking, and how unchecked desire, greed and wealth can quickly eliminate environmental treasures. I think the auks also symbolize regret. Regret of [sic] society's slow action to solve immediate problems, even when the negative consequences are clear.

These responses exemplify how the great auk has been interpreted by museum professionals at the Natural History Museum of Denmark as an icon of human failure to protect nature.

\section{A PEEPhOLE into The PRISTine North}

As a museum object, the great auk is strongly interlinked with the history and development of the Zoological Museum that later became the Natural History Museum of Denmark and its current role as a research institution, as discussed by Fjeldså \& Hatting (1985) and Lyngs (1994). In 1942, the great auk was even chosen as the logo for the Zoological Museum that is currently part of the Danish Natural History Museum, as mentioned above. According to my interviewees, the great auk logo from 1942 still pops up from time to time within diverse contexts. Despite the fact that a new logo was designed in 2004, when the Natural History Museum of Denmark was established, some members of the staff have kept their T-shirts, pins and mugs with the great auk logo. During my fieldwork at the museum, one of my informants showed me a small collection of great auk memorabilia, including pins, a T-shirt and a large, decorated plastic model with a colourful tie and sunglasses placed in in his office, and another informant gave me a few envelopes with the old logo (Fig. 5). ${ }^{7}$

When asked about the meaning of this old logo (Fig. 5), one staff member stated: "I think it was a very strong logo, and I think it was a 


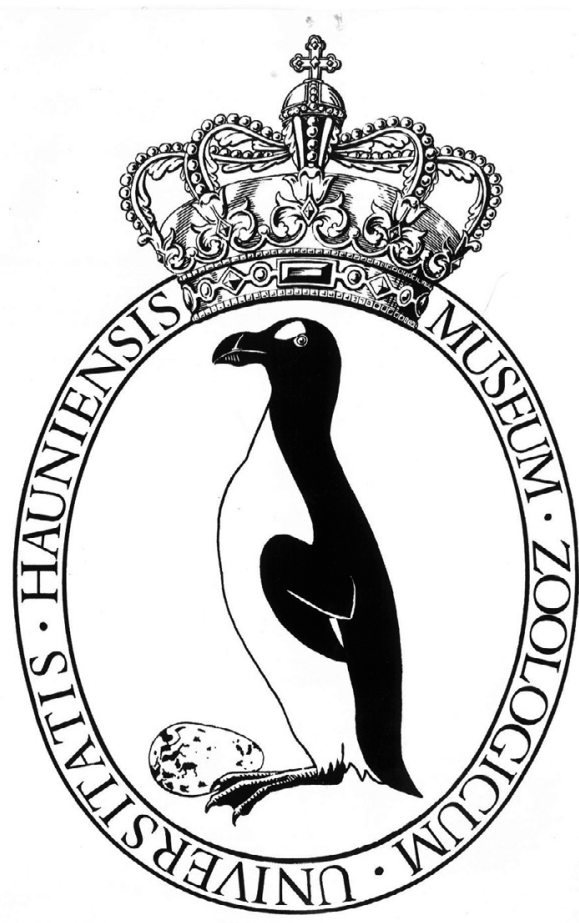

Fig. 5. The great auk logo from 1942, modified by Jon Fjeldså in 1986. Photo: The Natural History Museum of Denmark, 2019.

very good logo for a natural history museum. It is strong because it is related to old Danish history and, of course, Icelandic history. What we have now is confusing. I don't understand it." Another informant, who also took part in the same interview, replied: "Yes, the old logo was much better. Nobody understands the new one or what it means. It was just chosen because everything was supposed to have a corporate image" (Interviews with museum staff and professionals at the Natural History Museum of Denmark, January-August 2019). ${ }^{8}$

The logo, made hundred years after the Greenlandic specimen was bought from Mr. Heilmann, a then director of the
Royal Greenlandic Trading Company by the Zoological Museum, also shows how interlinked the great auk is in the history of the museum. It was, in fact, the former head of the Zoological Museum, Japetus Steenstrup (1813-1897), who called attention to the great auk (Lyngs 1994). Steenstrup (1857) also noted that the great auk was not an Arctic bird but a North-Atlantic bird. In his work, Streenstrup (1857) gathered information on the bird and their living conditions in Iceland, Greenland, Denmark, the Faroe Islands and the Scottish Isles. While it was "generally believed at the time that there were plenty of them up there, Steenstrup called attention to the fact that only very few individuals were still alive in that area and in the world" (Interviews with museum staff and professionals, September-October 2018 and January-August 2019).

Another example of how this former logo is currently used can be seen at the aforementioned exhibition, From the North Pole to the South Pole, where it has been placed within a glass cabinet, above the head of the plastic great auk item, as shown in the photograph in Fig. 6. Below the logo are a few lines that state that the great auk was chosen as a logo for the museum in 1942 without giving any more information about who designed it or why it was chosen. The royal undertones apparent in the former logo, with an emphasis on imperial ambitions and the Danish crown, evokes thoughts of past and present colonial complexities. The blue velvet cloth, placed under the plastic replica, adds another royal layer to the symbolism. The large glass case surrounding the plastic replica with the royal insignia above its head and blue velvet under its feet gives the item both importance and authority. ${ }^{9}$ A text panel beside it also takes part in contextualizing the great auk within a certain centre versus periphery narrative. 
On the panel, it is stated that when the last breeding stations were in Iceland, the country was still part of the Danish empire. The text also highlights the role and active part of the museum in collecting and preserving the last specimens with a brief explanation on how and why the organs ended up at the Zoological Museum in Denmark (the Natural History Museum of Denmark, September 2018). Through this narrative, the visitor is once again reminded of human/colonial overexploitation in the North Atlantic.

This large plastic great auk item, displayed as part of the exhibition From the North Pole to the South Pole (launched in 1974), also encourages thoughts on current human/ animal relations and continuing ecological challenges in relation to climate change and biodiversity loss. Together with the leather chair placed by the glass cabinet (Fig. 6) the plastic replica silently invites visitors to contemplate its meaning. The item shares exhibition space with other taxidermy animals from the North-Atlantic area, such as puffins from the Faroe Islands and gigantic walruses from Greenland. The plastic model (Fig. 6) is, however, displayed in a quite distinctive way. As shown in the photograph above, it has been placed alone in a different type of glass cabinet. The other animal objects, to use Poliquin's $(2008,2012)$ phrase, are placed two, three or four together in a row of glass cabinets, which gives the plastic great auk a rather lonesome aura but also quite impressive visual impact.

In Haraway's (1985) seminal analysis on Akely's Hall, she describes how taxidermy animals acted as symbols for the wild and untouched African nature. The stuffed animals were, in other words, used to represent an image of a pristine and desirable nature that did not exist in any physical African reality. In a similar way, the great auk items at the Natural

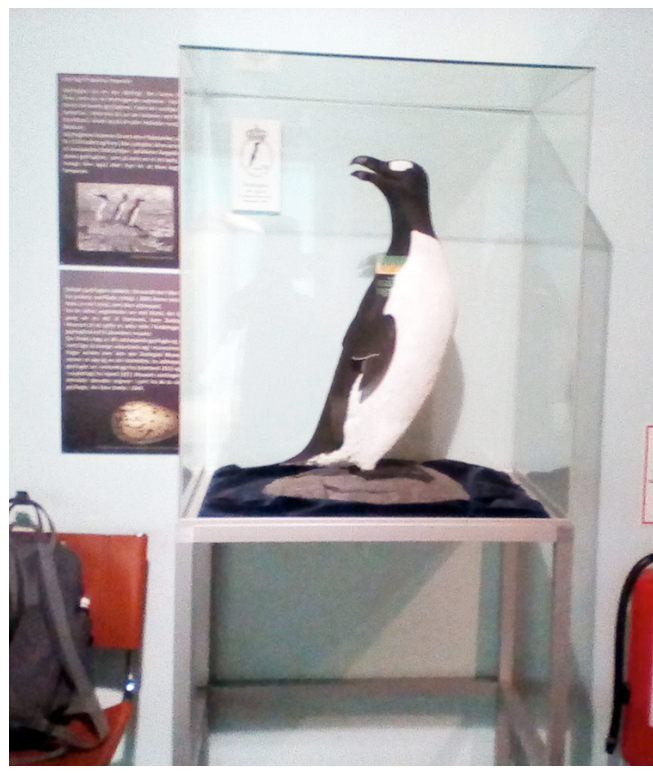

Fig. 6. The plastic replica, made by Ole Post, and the old logo within the glass cabinet at the Natural History Museum of Denmark. Photo: Katla Kjartansdóttir, 2019.

History Museum of Denmark also provide the viewer a peephole into the seemingly pristine North as imagined wilderness and wonderland. When visiting the exhibition From the North Pole to the South Pole, guests are invited to take a stroll through a type of frozen fantasyland of the wild and exotic North. When walking through the exhibition halls filled with stuffed animals in diverse shapes and sizes, including puffins, musk oxen, seals and colossal walruses from Greenland, I was reminded of Haraway's (1985) analysis on the symbolic role of taxidermied African animals, Snæbjörnsdóttir and Wilson's (2006) examination on mounted polar bears as cultural objects in British museums (and private homes) and Poliquin's (2012) discussion on taxidermies as tokens of deep human longing for preserving a 
vanishing natural world and desire for raw animal presence.

Local human inhabitants of the area are barely present and the exhibition hardly sheds any light on how important the great auk was in relation to livelihoods and survival in the cold climates of the North Atlantic, where the meat, oil and feathers of the great auk were necessary for clothes, food and other vital items. The black skin on their feet was, for instance, used to decorate white sealskin purses. Their skin, with feathers turned inward, was used for making a garment worn closest to the body. This kind of birdskin parka, or timmiaq in Greenlandic, was worn by both men and women during wintertime. ${ }^{10}$

The tragic fate of the extirpated great auk seems to have gained more attention within contemporary museum narratives at the Natural History Museum of Denmark over its past importance as a source of livelihood in the cold climates of the North-Atlantic area where fat and downy birds, like the great auk, were, in fact, vital for survival. These examples also highlight the change in its value as a commodity in diverse forms and importance for different groups.

\section{CONTEMPORARY ROLE OF THE GREAT AUK}

The great auk can be seen as a "slow event" (Kirshenblatt-Gimblett 2004): its symbolic meaning has been developing slowly over time. The cultural biography and afterlife of the great auk, as a museum object, also shows how shifting mindsets regarding human/ animal relations and ideas about nature have influenced the ways in which the bird has been displayed as a museum object from the 17 th century to the present, and how these diverse museum narratives have influenced it's symbolic meaning. The items encourage visual and material representations continually shape our ideas about animals and our complex relationships with them, both historically and in the present. The diverse materiality of the objects also draws attention to the role, affect and value of (plastic) copies, authenticity and original treasures attained from colonies and elsewhere. When visiting the Greenland Institute for Natural Resources and the National Museum of Greenland in Nuuk, one only finds plastic replicas of the great auk made as well by the aforementioned Ole Post, a former conservator at the Natural History Museum of Denmark (Interviews with museum staff and professionals, SeptemberOctober 2018 and January-August 2019).

When looking at and touching the original mounted bird specimen from Greenland (Fig. 3), I could almost feel subtle traces of complex past social relations; cross-cultural entanglements, emotions and narrations run through the materiality of the item. It was as if some kind of melancholic (post-colonial) aura encircled the object and I was reminded of how it once operated as an exotic commodity and a conveyor of knowledge about the NorthAtlantic area.

The plastic item (Fig. 6) exhibited as part of the exhibition From the North Pole to the South Pole has, however, quite a different effect with more playful or even humorous undertones. According to one of my informants, several plastic replicas of this kind were made for a traveling exhibition in 1986 (e-mail correspondance, 26 March 2019). The posture of the replica seemed chirpy and when looking closely I could see that the beak was open. These artistic details underline the agency and thing power (Bennett 2004) of this item. It actually seemed to be prepared for a serious 
54 dialogue with the viewer. The plastic feel and artificiality of this plastic replica also gave the two mounted birds hunted in Iceland and Greenland a greater sense of authenticity. These unique museum items have great historical and international value. As discussed above, they can evoke thoughts and discussions on the history, responsibility and participation of natural history museums in relation to human exploitation of species in the past.

These museum objects - and other taxidermies of the great auk - can also be valued as active contributors in current discussions on the emerging biodiversity crisis, climate change, continuing nature/culture tensions, complex human/animal relations and other collective ecological challenges. As dark reminders of short-term (human centred) thinking they can be activated when it comes to urgent matters of our contemporary posthuman, post-anthropocentric times. With the sixth mass extinction underway (Kolbert 2014) their message has become quite urgent. To echo Strauss (1964) who famously said that animals are good to think with, the example of the great auk demonstrates that extinct birds are also quite good to think with. Mutely, they invite museum visitors to mourn over what has been lost while highlighting the importance of safeguarding what is left.

\section{Noter}

1. This paper is written within the framework of the project Mobility and Transnationalism in Iceland, where the main goal is to understand how Iceland has been shaped by different kinds of mobilities and transnationalism. The project is funded by The Icelandic Centre for Research (RANNÍSGrant number 163350-051).

2. Troughout the article I use the North and the Arctic interchangeably to describe the North-
Atlantic area as a geographical place and imagined space.

3. See Mordhorst (2003) for further discussion on Worm's cabinet and the aims of his collection.

4. Worm's interest in peculiar animals has been emphasized by Mordhorst (2003), but according to her, Worm was interested in the South American coati, the armadillo and lemminger but not so much in common Danish animals such as dogs, foxes or mice. Mordhorst (2003) also mentions that Worm actually had a living armadillo for five years in his cabinet, collected from Amsterdam in 1649.

5. This item has been displayed in several museums in Iceland but is currently kept in storage at the Icelandic Institute of Natural History (e-mail correspondence, September 11 2019, with museum professional at the Icelandic Museum of Natural History).

6. See, for example, Loftsdóttir (2015) for discussion on the savage as part of the image of the exotic North.

7. Other examples include small great auk statues made by Ole Post, a former conservator at the museum. These statues were usually given to staff members on occasions such as anniversaries or retirements.

8. The Natural History Museum of Denmark was established in January 2004 by the merging of four institutions: The Botanical Garden, the Botanical Museum and Central Library, the Geological Museum and the Zoological Museum.

9. See, for example, Brenna (2013) for discussion on the role of glass within museums.

10. Oldendown 1935, Fjeldså and Hatting 1985, Fabricus 1808 in Meldgaard 1988 give examples of this kind of usage. For visual examples of similar bird skin parkas made from little auk skin, see British museum online collection, search word: "bird skin parka" https://www.britishmuseum.org/research/ collection_online/collection_object_details. 


\section{THE CHANGING SYMBOLIC MEANING OF THE EXTINCT GREAT AUK AND ITS AFTERLIFE as a museum object at the Natural History Museum of Denmark}

aspx?objectId $=532620 \& p a$

rtId $=1$ \&ethname $=6639$ \&page $=1$

Accessed August 29 2019. Greenlandic translation by Rosannguaq Rossen (e-mail correspondence, 13.09. 2019).

\section{INTERVIEWS}

Kjartansdóttir, Katla 2018-2019. Interviews with museum staff and professionals at the Natural History Museum of Denmark, SeptemberOctober 2018 and January-August 2019.

\section{LITERATURE}

Bennett, Jane 2004. "The force of things: Steps toward an ecology of matter." Political Theory 32:3, 347-372.

Bennett, Jane 2010. Vibrant Matter: A Political Ecology of Things. Durham: Duke University Press.

Brenna, Brita 2013. "The frames of specimens: Glass cases in Bergen Museum around 1900." In Liv Emma Thorsen, Karen A. Rader \& Adam Dodd (eds.). Animals on Display: The Creaturely in Museums, Zoos, and Natural History. Pennsylvania: The Pennsylvania State University Press, 37-58.

Byrne, Angela 2013. Geopgraphies of the Romantic North. Science, Antiquarianism, and travel, 17901830. New York: Palgrave.

Davidson, Peter 2005. The Idea of North. London: Reaktion Books.

Della Dora, Veronica 2009. "Travelling landscapeobjects." Progress in Human Geography 33:3, 334-354. doi 10.1177/0309132508096348.

Ferrando, Francesca 2013. "Posthumanism, transhumanism, antihumanism, metahumanism, and new materialisms differences and relations." An International Journal in Philosophy, Religion, Politics and the Arts 8:2, 26-32.

Fjeldså, Jon \& Tove Hatting 1985. "Museets bomærke: Gejrfuglen. Nye aspekter om den forlængst uddøde fuglearts skæbne." Dyr i Natur og

Museum. Copenhagen: Zoologiske Museum, 13-19.

Foucault, Michael 1970. The Order of Things. New York: Random House.

Fuller, Eroll 1999. The Great Auk. New York: Abrams.

Gremaud, Ann-Sofie 2014. "Power and purity: Nature as resource in a troubled world." Environmental Humanities 5, 77-100.

Grieve, Symington 1885. The Great Auk or Garefowl Alca Impennis, its history, Archeology and Remains. London: Thomas C. Jack.

Grieve, Symington 1897. Supplementary Note on the Great Auk or Garefowl (Alca Impennis Linn.) Edinburgh: William Blackwood and Sons.

Hafstein, Valdimar 2010. "Pekking, virðing, vald: Virtúósinn Ole Worm og Museum Wormanium í Kaupmannahöfn.” Ritið 10:1, 25-27.

Haraway, Donna J. 1985. "Teddy bear patriarchy. Taxidermy in the garden of Eden, New York City, 1908-1936." Social Text 11, 20-64.

Haraway, Donna J. 2000. "A manifesto for cyborgs: Science, technology, and socialist-feminism in the 1980s." In Gill Kirkup, Linda Janes, Kath Woodward \& Fiona Hovenden (eds.). The Gendered Cyborg: A Reader. New York, London: Routledge, 50-57.

Kirshenblatt-Gimblett, Barbara 2004. "Intangible heritage as metacultural production." Museum International 56:1/2, 52-65.

Kjartansdóttir, Katla 2009. "Remote, rough and romantic. Contemporary images of Iceland in visual, oral and textual narrations." In Sverrir Jakobsson (ed.) Images of the North: Histories Identities - Ideas. New York: Rodopi, 271-280.

Kjartansdóttir, Katla \& Kristinn Schram 2013.

"Something in the Air." In Peter Aronsson \& Lizette Gradén (eds.). Performing Nordic Heritage. London: Ashgate, 53-71.

Kolbert, Elizabeth 2014. The sixth Extinction: An Unnatural History. New York: Henry Holt. Latour, Bruno 1987. Science in action: how to follow 
scientists and engineers through society. Cambridge Mass: Harvard University Press.

Lévi-Strauss, Claude 1964. Totemism; translation from French by Rodney Needham. Merlin Press: London.

Loftsdóttir, Kristín 2015. “The exotic north: Gender, national branding and post-colonialism in Iceland." Nora 23:4, 246-260.

Lorimer, Jamie 2014. "On auks and awkwardness" Environmental Humanities 4, 195-205.

Lund, Katrín, Katla Kjartansdóttir and Kristín Loftsdóttir 2017. "Puffin love: Performing and creating Arctic landscapes in Iceland through souvenirs." Tourist Studies 18:2, 142-158.

Lynge, Pete 1994. "Gejrfuglen - Et 150 års minde." Dansk Ornitologisk Forenings Tidsskrift 88:2, 49-71.

Meldgaard, Morten 1988. "The Great Auk, Pinguinus Impennis (L.) in Greenland.” Historical Biology 1, 145-178.

Mordhorst, Camilla 2003. Genstandsfortellinger. Fra Museum Wormianum til de Moderne Museer. Ph.d. Afhandling. Roskilde Universitetscenter/ Nationalmuseet.

Morton, Timothy 2007. Ecology Without Nature: Rethinking Environmental Aesthetics. Harvard University Press.

Morton, Timothy 2010. The Ecological Thought. Harvard University Press.

Morton, Timothy 2013. Hyperobjects: Philosophy and Ecology after the End of the World. Minneapolis: University of Minnesota Press.

Newton, Alfred 1861. "Abstract of Mr. J. Wolley's Researches in Iceland respecting the Gare-fowl or Great Auk (Alea impennis, Linn.)." Ibis. 3:4, 374-399.

Oldendown, Knud 1935. Naturfredning i Grønland. Köbenhavn: G.E.C. Gaads Forlag. Olsen, Bjørnar \& Póra Pétursdóttir 2014. Ruin memories: Materialities, aesthetics and the archaeology of the recent past. Milton Park, Abingdon, Oxon: Routledge.

Petersen, Ævar 1995. "Brot úr sögu geirfuglsins." Náttúrufreðingurinn 65:1-2, 53-66.

Poliquin, Rachel 2008. "The matter and meaning of museum taxidermy." Museum and Society 6:2, 123-134 .

Poliquin, Rachel 2009. Ravishing Beasts: The Strangely Alluring World of Taxidermy. Vancouver: Museum of Vancouver.

Poliquin, Rachel 2012. The Breathless Zoo: Taxidermy and the Cultures of Longing. University Park, PA: Pennsylvania State University Press.

Shackelford, Jole 1999. "Documenting the factual and the artifactual: Ole Worm and Public Knowledge." Endeavour 23:2, 65-71.

Snæbjörnsdottir, Bryndís \& Mark Wilson 2006. Nanoq: Flat Out and Bluesome: a Cultural Life of Polar Bears. London: Black Dog Publishing.

Stager, Hanne 2015. Precious Things. The Greatest Treasures of the Museum. Copenhagen: Statens Naturhistoriske Museum.

Steenstrup, Japetus 1857. "Et Bidrag til Geirfuglens Naturhistorie og Særligt til Kundskaben om dens Tidligere Udbredelseskreds." Vidensk. Meddr naturh. Foren. Kjöbenhavn 3-7:33-118.

Worm, Ole \& Jakob Benediktsson 1948. Ole Worm's correspondence with Icelanders. (Bibliotheca Arnamagnæana). Copenhagen: Munksgaard.

Katla Kjartansdóttir, PhD student katlak@hi.is

Department of Ethnology/Folklore and Museum Studies University of Iceland Ásvallagata 21, 101 Reykjavík, Iceland 